NACIONES UNIDAS

AÑO INTERNACIONAL DE LA FAMILIA 2004

FAMILIES IN THE PROCESS OF DEVELOPMENT

\title{
FAMILY IN THE NEW MILLINEUM: MAJOR TRENDS AFFECTING FAMILIES IN NORTH AFRICA
}

\author{
NAZEK NOSSEIR
}

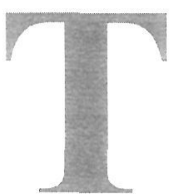

\section{INTRODUCTION}

he family has always been the basic unit of the social structure in traditional Arab society. It has also maintained that crucial position in contemporary society in the Arab world. However, the situation of the family needs to be examined in the context of the significant changes that the region has been witnessing. Such changes as those in social organization, may have had an impact on prevailing values. These changes are likely to require social transformations first and foremost in the family.

For better understanding of those changes, it is of paramount importance to highlight some of the basic characteristics of the Arab family. Being at the focal point of society, the family is best described as patriarchal, with a pyramidal hierarchy particularly with respect to age and sex, and maintains extended ties. To a large extent the family continues to be an economic and social unit within society. Members of the family still cooperate together in order to support its continuity as well as improve its well being in the community. Enterprises as well as all other sorts of property are commonly owned and operated for the benefit of all members.

This pattern of living is witnessed among Bedouins, rural as well as urban dwellers in the region. It is the social institution with which individuals identify most. In Arab societies, such as those of North Africa, people inherit their religion, class and cultural identity from their families. At all times, and particularly in times of emotional stress and physical need, the family is there to provide security and support for its members. The success or failure of one member is borne by all other family members. 
This arrangement may require a substantial amount of commitment and perhaps self-denial at times. Both parents and children are committed to undertake what is best for the family. That may demand that parents, particularly mothers, deny themselves for the sake of their children. The happiness and success of the children is the source of happiness of the mother. In fact, this relationship is mutual as well as reciprocal. In Arabic the concept of family is 'aila. The root of this Arabic word means "to support". In young age, the role of the father is to provide for and support the other family members, while the role of the mother is to look after the children and take care of the household activities. As the children mature and parents grow old, it becomes the responsibility of the children to look after and support their parents in old age.

Barakat (1993) argues that family loyalty could explain why many parents still want to have large numbers of children. This is because in rural communities and among the urban poor, children are sent to work and earn money from a very young age. Therefore, an additional child is seen as an extension of family power and prestige as well as an extra source of income, rather than another mouth to feed and another person to educate.

\section{OBJECTIVES OF THE STUDY}

The family is the most important institution in Arab society, as it meets social, political and affective needs of its members. In addition, it provides employment and wealth for both male and female members. Has the family institution been affected by sweeping social changes rocking various aspects of the social organizations within society? In many parts of the world one can see major changes with noticeable impact affecting families. Families have been reduced structurally from the extended form to the nuclear. Lately, one parent families have been increasing and so has the "single person" household - which can hardly be labeled as a family. Functionally, also, major changes have taken place that encouraged the family to delegate some of its cherished roles to other more specialized institutions in society. More specifically, a major part of the socialization of children has been turned over to specialized institutions such as day care centers. Education of children is largely handled by schools. For employment, many seek work outside family enterprises.

For the purposes of this paper, the family in the North Africa region will be studied. Included in this study are the following Arab countries: 
Algeria, Egypt, Libyan Arab Jamahiriya, Morocco, Sudan and Tunisia. More specifically the objectives of the study are:

1. To investigate the impact of some major trends on families in the North Africa region within the recent past,

2. To examine new challenges that may be facing families in the region,

3. To suggest policy guidance for implementation.

\section{MAJOR TRENDS AFFECTING FAMILIES}

The following five major trends have been selected for investigation in this study:

1st. Changes in family structure - including issues such as smaller size households, delayed age at first marriage and its impact on childbearing, polygamy, change in divorce rates, and rise in single parenthood,

2nd. Rise in migration,

3rd. Demographic aging and its social and economic implications,

4th. The HIV/AID pandemic,

5th. Impact of globalization.

\subsection{Changes in Family Structure}

In the traditional Arab family, the father represents the authority figure (patriarchal tradition), and in return he shoulders the major responsibilities towards his family members. The wife joins the kin group of her husband (patrilocal kinship), while the children take up the father's family name (patrilineal descent). In that capacity, the father is assigned the role of the bread-winner or provider for his family. This role puts him at the top of the pyramidal structure of his family. Also this role carries with it unquestioning compliance with his instructions as well as respect from all family members. The mother is assigned the role of the housewife, and in that capacity, she is closer to the children and actually exercises power over them, though sometimes she may use the father to threaten them. Some scholars may interpret that as a matriarchal system alongside the patriarchal system in the Arab family. Barakat (1993), however, argues that this matriarchal system supports the existing patriarchy, as it solidifies the pyramidal structure of the family. 
Studies (see Barakat, 1993 and Hopkins and Ibrahim, 1997) seem to indicate that in the early days this division of labor within the family satisfied both husbands and wives with all the rights and duties that were attached to these roles. However, Amin (2000) argues that with the rising cost of living, men started to value women who could share in the household expenses. In turn, this led to a preference for fewer children and a relation characterized by more affection and mutual respect.

The hierarchical structure of the family rests on two axes: age and sex. The young are compliant to the old, and women are compliant to men. Traditionally, the source of authority and power that the father exercised stemmed from the fact that he was in possession of the family property and controlled it. This compliance of the young and of females is acquired through socialization. Various agents of socialization are involved in this process starting with the families that emphasize in their children obedience, dependency and inequality between the male and female children. The educational institutions are also involved by emphasizing physical punishment and rotelearning, shunning away challenges and independent creative thinking. While children are expected to depend on their parents when they are young, this role is reversed when the parents grow old, it is expected that their children take care of them even at the expense of their own personal interest.

More recently and as a result of various structural changes, employment of women, migration of the children in search of educational and work opportunities, the strict patriarchal traditions began to be transformed. Accordingly, fathers began to loosen their hold over other family members, and share authority and responsibility with them. Nonetheless, the family in the Arab world still remains patriarchal as well as hierarchical in structure.

The extended family, in the traditional sense of three or more generations living together under the same roof, rarely exists now in the North African region. Most studies point out that the large majority of families are nuclear in structure (see Tables 1 and 2). This came about as a result of urbanization, industrialization, increased education, migration, and extension of government employment. However, it should be noted, that nuclear families continue to maintain intimate and close ties with other relatives. Though living under separate roofs, interdependence is fostered through intermarriage as well as collaboration in economic activities.

Research on the family has lately been overshadowed by the study of gender, more specifically studies of women, in terms of the major changes that have impacted their lives and their responses to the new 
Table 1: Distribution of Household By Type of Households (EDHS 1995)

\begin{tabular}{lc|}
\hline TYPE OF HOUSEHOLD & $\%$ of Households \\
\hline Single-person household & 5.4 \\
Nuclear-family household & 75.1 \\
Extended family household & 19.5 \\
Composite household & $<0.05$ \\
\hline
\end{tabular}

Source: Khadr and El-Zeini, 2001, p. 148.

Table 2. Average Size of Household

\begin{tabular}{l|c|c|c}
\hline COUNTRY & 1992 & 1995 & 2000 \\
\hline Algeria $^{1}$ & 6.9 & & \\
Egypt $^{2,3,4}$ & 9 & 5.3 & 5.2 \\
Libyan Arab Jamahiriya $^{5}$ & 5.6 & 7.8 & \\
Sudan $^{6}$ & 6.6 & & \\
\hline
\end{tabular}

Source:

1. Algeria Maternal and Child Health Survey: 1992. Algiers: National Office of Statistics (Algiers) and Cairo: PAPCHILD/League of Arab States, 1994.

2. El-Zanaty, F., H. Sayed, H. Zaky, and A.A. Way. Egypt Demographic and Health Survey, 1992. Cairo: National Population Council and Calverton Maryland, USA: Macro International Inc., 1993.

3. El-Zanaty, F., E.M. Hussein, G.A. Shawky, A.A. Way and S. Kishor. Egypt Demographic and Health Survey, 1995. Cairo: National Population Council and Calverton, Maryland, USA: Macro International Inc., 1996.

4. El-Zanaty, F, and Ann A. Way. Egypt Demographic and Health Survey, 2000. Calverton, Maryland [USA], Ministry of Health and Population [Egypt], National Population Council and ORC Macro, 2001.

5. Libya Maternal and Child Health Survey 1995. Tripoli: General Committee for Health and Social Security and Cairo: PAPCHILD/League of Arab States, 1997.

6. Sudan Maternal and Child Health Survey 1992/93. Khartoum: Federal Ministry of Health and Cairo: PAPCHILD/League of Arab States, 1995.

challenges they face. Nonetheless the two areas are closely connected, and at times may overlap, though they may not be the same. According to many researchers, the shape of the family and the role it performs are closely tied to the status and role of women in both the family and in society at large.

Amin (2000) discusses the changes in the position of women over the past 50 years. He argues that in the earlier days, a wife had to "clip her husband's wings ... and ... the most effective way of achieving this was to bear him as many children as possible." (p. 81) In addition, he also maintains that in those days, women had to tolerate many things of their husbands that wives nowadays would find unforgivable.

It is the consensus of most scholars that women in Arab countries including North Africa still suffer an inferior status. However, they may disagree with respect to the extent of this inferiority and what is needed to improve this situation (see Barakat, 1993, Mc Murray, 1993). 
According to the views of some progressive writers, the inferiority of women in Arab society is best explained in terms of the existing socioeconomic conditions and for women to emerge out of the current situation, all forms of exploitation and segregation have to be lifted (see Amin, 2000, Gocek and Balaghi, 1994).

This inferiority of females begins at an early age within the family. Girls may be required to drop out off school to look after their younger siblings. Veiling -which is considered by some scholars a sign of seclusion and segregation- is widespread. Though according to recent statistics, more females are being educated and taking up paid jobs, however, the large majority still maintains solely the household responsibility. It should also be noted that there are certain professional careers that are not made available for women, e.g. in Egypt, the first woman judge was appointed by a presidential decree only in January 2003. With respect to personal status codes, women still suffer under present systems particularly in areas of marriage, divorce, custody of children and inheritance. In some parts of the Arab world, women are banned from inheritance, though Islam has granted inheritance rights to females as half of what her brothers inherit. In Tunisia, women inherit an equal share compared to men.

Some scholars have noted that although civil laws in many Arab societies are deduced from European legislation, family laws regulating marriages, divorces inheritance and custody of children are derived from the Qur'an and Sunna. With respect to marriage, it is considered the duty of every believer to be married. Therefore, demographic censuses show a high frequency of marriage among those populations, showing that 95 to 100 percent of men and women who are 45 years old and older have been married (see Fargues, 2001).

Among families in North Africa, marriage is still considered as union between two families rather than union between two individuals. It is meant as a way of reinforcing family ties and interests, preserving property through inheritance, as well as the mechanism for reproduction. Thus most marriages are still arranged and endogamous.

In 1923, a law was passed in Egypt that set the minimum age of marriage for girls at 16 years and for boys at 18 years. Likewise in Tunisia the Personal Status Code passed in 1956 specified a minimum age of marriage for girls. In spite of these laws, there were situations in which girls were married before reaching this legal age. However, recent survey data indicate a significant increase in the mean age at first marriage (Table 3), which has been attributed to the influence of schooling (Table 4). The data in Table 4 show that the median age at 
Table 3: Average Age at First Marriage in North Africa Region

\begin{tabular}{l|c} 
COUNTRY & AVERAGE AGE AT FIRST MARRIAGE* \\
\hline Algeria & 24 \\
Egypt & 19 \\
Libyan Arab Jamahiriya & - \\
Morocco & 20 \\
Sudan & 24 \\
Tunisia & 25 \\
\hline
\end{tabular}

Source: Population Reference Bureau: The World Youth 2000. www.prb.org * May include formal and/or informal unions.

Table 4: Median Age at First Marriage By Age Groups, 1986-1992 in Selected Countries in North Africa Region

\begin{tabular}{l|c|c|c|c|c|c|c|}
\hline & \multicolumn{7}{|c}{ AGE GROUP } \\
\hline COUNTRY & $\mathbf{2 0 - 2 4}$ & $\mathbf{2 5 - 2 9}$ & $\mathbf{3 0 - 3 4}$ & $\mathbf{3 5 - 3 9}$ & $\mathbf{4 0 - 4 4}$ & $\mathbf{4 5 - 4 9}$ & $\mathbf{2 5 - 4 9}$ \\
\hline Egypt & NA & 19.5 & 19.0 & 18.2 & 17.8 & 17.4 & 18.5 \\
Morocco & NA & 22.3 & 20.0 & 19.4 & 18.6 & 17.6 & 19.7 \\
Tunisia & NA & 22.9 & 21.3 & 20.6 & 19.4 & 19.9 & 21.1 \\
\hline
\end{tabular}

Source: DHS/EDS, 1986 - 1992. WWW.UNECA FSSD/Population/Women (on-line).

first marriage rises gradually among younger cohorts of women. Thus it is clear from the table that the overall median age at first marriage for females 25 to 49 is consistently higher than the median age at first marriage for females 35 years and older in all three countries. On the other hand, overall median age at first marriage is lower than that for younger cohorts below 35 years of age.

Within the countries of North Africa, regional variations lead to wide disparities in the structure, function and values of the family. Urban families are increasingly moving towards egalitarian relations among members. With more wives educated and gainfully employed, thus contributing financially to the household budget, they -in return- have acquired implicit, and sometimes explicit rights in decision making processes. In Egypt and Tunisia, women's participation in the labor force was around 15\% in 1995 and has risen especially in public and government sectors. According to the law in Algeria, Tunisia and Egypt women are treated equally to men in work in terms of pay and other fringe benefits.

Some recent studies show that more young men prefer to seek marriage to working women (see Labidi, 2001, p. 129). The salary of the woman raises the standard of living. It is worth noting that the engagement of women with work outside the home requires the acquisition and use of labor-saving devices, such as washing machines, vacuum cleaners, 
etc., to aid in the household chores. Most of these appliances in the countries under study are expensive, but they could be bought on credit. This choice is often made because the use of such equipment allows women to look after other family needs such as supervising children's homework and leisure time activities.

In addition to the fact that people are marrying at a later age, there has been also an observed decline in the age difference between spouses. This has contributed to a change from marriage as a subordination of wife to husband, to a more egalitarian relation between husband and wife.

The Tunisian Personal Status Code (PSC) declared in 1956 outlawed polygamy, a right given by Islam to men, which entitles them to marry up to four women simultaneously - though it stipulates that in order to do so, men should be financially capable to support more than one wife and morally able to treat all wives fairly. According to the PSC, which is considered a de facto constitution, divorce had to take place in courts of law in the presence of a judge. In addition, the PSC provided other reforms that introduced major changes in the lives of women within the family, as well as in public space. Such reforms include specifying a minimum age of marriage for girls, designating that schools be coeducational to provide girls with more educational opportunities, equating salaries of women to that of men for equal type of work. Many of these reforms led to improving the status of women, and her increased participation in public space. In 1993, more reforms were introduced in Tunisia that further enhanced the position of the Tunisian women. Some of these reforms dealt with the reciprocal obligations of husband and wife, domestic violence, and the acquisition of nationality through the mother. All these reforms introduced in Tunisia over the past half century have had their impact on the family in transforming some of the values that govern the relationship among the family members.

In Egypt, children born to an Egyptian mother and non-Egyptian father cannot claim Egyptian nationality, with all the rights that pertain to it. In Al-Ahram newspaper on September 24, 2003, a short story was presented that attested to the right of such women to apply to the proper authorities to grant their children born of a non-Egyptian father, the Egyptian nationality.

Polygamy is declining in most Arab societies. Tunisia is the only country that outlawed it with the adoption of the Personal Status Code in 1956. Elsewhere, the percentage of polygamous marriages range from 2 to 5 percent, with the exception of Sudan in which this percentage is higher. Interstingly, an increase in polygamous marriages was observed 
in Egypt in the last quarter of the 20th century. This phenomenon has been attributed to the 'infitah' -open door policy- which was a period of economic blooming. Concomitant with that was the increase in informal marriage 'Urfi marriage' during this period, which is not legally registered. This form of marriage occurred mainly either as a polygamous marriage, or among young people such as college students in which case both -the man and the woman- have not married before.

In another study, Fargues (2001) attributes polygamy to the conditions of high fertility and high mortality prevalent in countries of that region for the greater part of the last century. He argues that it is evident that younger cohorts are numerically larger than older ones, therefore, it was estimated that for every 100 females aged $15-19$ years, there would be 91 males aged 2024 years and 80 males aged $25-29$ years. Since the age difference between husbands and wives in many studies has been found to be around seven years, given the above figures and the universality of marriage, it is most likely that some of those females will marry for the first time older, non-single males (polygamy) or divorced males.

According to Islam, in case of disagreement between husband and wife, a number of remedial steps to reconcile have to be taken, and if they all fail, then divorce takes place. In practice, however, husbands easily divorce their wives, if they so wish, whereas it is difficult for a wife to divorce her husband against his will. Though Islam has granted women the right to initiate divorce, it requires that this right be clearly stated in the marriage contract. In Egypt, research has shown that the large majority of women are ignorant of that right, and among those who know of it, many are reluctant to use it. Since 1960, an Egyptian husband seeking a divorce must state his reason for doing so in court. In Tunisia and Algeria, divorce proceedings take place in court.

According to the law in Tunisia, the judge cannot grant a divorce without looking into the reasons that may have led to that, and should try to counsel the couple. In Morocco, the personal status laws require the judge to record the husband's decision to seek a divorce.

Studies show that divorce is most likely to occur early in marriage. Infertility seems to be the main cause for breaking up a marriage. Despite existing divorce rates, the negligible numbers of individuals whose marital status is listed as "divorced", according to censuses particularly males, could be an indication of remarriage (Fargues, 2001).

According to Table 5 the divorce rates for Egypt and Libya, over the past quarter of a century have shown steady declines, while Tunisia has experienced minor ups and downs. One way of explaining this, is in terms of the prevalence and durability of the family institution in the 
Table 5: Divorce Rate in North Africa Region

\begin{tabular}{l|c|c|c|c}
\hline YEAR & Algeria & Egypt & Libyan Arab Jamahiriya & Tunisia \\
$\mathbf{1 9 8 0}$ & - & 1.63 & 1.31 & 1.11 \\
$\mathbf{1 9 8 1}$ & - & 1.58 & 1.17 & 0.83 \\
$\mathbf{1 9 8 2}$ & - & - & - & 0.95 \\
$\mathbf{1 9 8 3}$ & - & - & - & 0.83 \\
$\mathbf{1 9 8 4}$ & - & - & 0.80 & 1.04 \\
$\mathbf{1 9 8 5}$ & - & 1.64 & 0.97 & 0.82 \\
$\mathbf{1 9 8 6}$ & - & - & 0.87 & - \\
$\mathbf{1 9 8 7}$ & - & - & 0.79 & 1.10 \\
$\mathbf{1 9 8 8}$ & - & - & 0.60 & 1.34 \\
$\mathbf{1 9 8 9}$ & - & - & - & 1.60 \\
$\mathbf{1 9 9 0}$ & - & - & - & - \\
$\mathbf{1 9 9 1}$ & - & - & 0.5 & 1.47 \\
$\mathbf{1 9 9 2}$ & - & 1.41 & - & - \\
$\mathbf{1 9 9 3}$ & - & 1.37 & - & - \\
$\mathbf{1 9 9 4}$ & - & 1.55 & - & 0.85 \\
$\mathbf{1 9 9 5}$ & - & 1.18 & 0.23 & 0.86 \\
$\mathbf{1 9 9 6}$ & - & 1.17 & 0.24 & 1.02 \\
$\mathbf{1 9 9 7}$ & - & 1.18 & - & 1.04 \\
\hline
\end{tabular}

Source: UN. Department of Economic and Social Affairs. Demographic Yearbook. New York: United Nations (for years 1980 - 1997).

region, as well as the irreducibility of cultures and their reluctance to allow globalization to enter the domain of values and private behavior (Fargues, 2001). Another observation in this regard is that the decline in the divorce rate accompanies the evolution of Arab legislation on family matters, particularly those pertaining to women's rights.

The impact of some of the above observed demographic changes, such as the rising median age at marriage, which is also coupled by an increase in the numbers who remain unmarried (see Rashad and Osman, 2001), has contributed to an observed decline in fertility rates. All of that was preceded by substantial decline in mortality. An obvious outcome is the increase in the proportion of the aged population.

Fertility rates in countries of the North Africa region have shown a significant decline even by international standards (UNDP, 2002). Tunisia demonstrates the lowest fertility rate in the region. Tunisia's fertility rate of 2.1 births per woman is lower than the world average of 2.7 births per woman. Algeria's TFR (2.8) is close to the world average. The remaining countries: Algeria, Egypt, Libyan Arab Jamahiriya, Morocco and the Sudan have fertility rates between three and five births per woman (see Table 6).

Most scholars agree that although overall statistics point out that fertility in North Africa had shown a substantial decline, there are still wide disparities in average fertility within each of those 
Table 6: Fertility Rates in North Africa Region*

\begin{tabular}{|l|l|l|}
\hline COUNTRY & SOURCE AND YEAR & TFR \\
\hline \multirow{4}{*}{ Algeria } & WFS 1986 & 5.4 \\
& PAPCHILD 1992 & 4.4 \\
& PRB 2002 & 2.8 \\
\hline \multirow{5}{*}{ Egypt } & WFS 1980 & 5.3 \\
& CPS 1984 & 4.9 \\
& DHS 1988 & 4.4 \\
& PARCHILD 1991 & 4.1 \\
& DHS 1992 & 3.9 \\
& DHS 1995 & 3.6 \\
Libyan Arab Jamahiriya & DHS 2000 & 3.5 \\
\hline \multirow{5}{*}{ Morocco } & PAPCHILD 1995 & 4.1 \\
& PRB 2002 & 3.7 \\
\hline \multirow{2}{*}{ Sudan } & WFS 1979/80 & 5.9 \\
& DHS 1988 & 4.5 \\
& DHS 1995 & 3.6 \\
& PRB 2002 & 3.1 \\
\hline \multirow{3}{*}{ Tunisia } & WFS 1984/86 & 5.6 \\
& PRB 2002 & 4.9 \\
\hline
\end{tabular}

WFS $=$ World Fertility Survey

PAPCHILD = Pan Arab Program for Child Development.

PRB = Population Reference Bureau World Population Data Sheet 2002.

DHS $=$ Demographic and Health Survey

* Data provided by Dr. Ann A. Way, MEASURE DHS+ Project, ORC Macro.

countries (Fargues, 1997, p. 78). Average fertility in areas closer to the Mediterranean is much lower than in areas farther away. Therefore, scholars conclude that these countries are still in the transitional stage, demographically speaking.

Studies of Tunisian families (see Labidi, 2001, p. 127) show that in case of domestic violence, the level of the wife's education does not seem to be the determining factor of whether the woman will file a complaint to the police. However what seems to make a difference is her economic independence, which seems to offer her some recourse against her husband's domination.

A number of social scientists have noted with some concern the impact of recent socio-economic and demographic changes, and changes in deep rooted value systems and corresponding norms upon the family in the Arab region, including countries in North Africa. Their concern is with respect to the emergence and growing increase in the numbers of female-headed households and one-person households (Table 7) (see Rashad and Osman, 2001, and Khadr and El-Zeini, 2001). These studies indicate that at least ten percent of the households in the region are headed by a female. Most of these households are found in urban areas. 
Table 7: Percentage of Female - Headed Households in North Africa Region

\begin{tabular}{|l|c|}
\hline COUNTRY & DATA \\
\hline Algeria & $11^{*}$ \\
\hline Egypt & 13 \\
\hline Libyan Arab Jamahiriya & - \\
\hline Morocco & 15 \\
\hline Sudan & $13^{*}$ \\
\hline Tunisia & $11^{*}$ \\
\hline
\end{tabular}

Source: Population Reference Bureau 2002 Women of Our World. www.data.worldpop.org/ * Data refer to year prior to that indicated.

The large majority of those females are above 50 years old and have been widowed or divorced. Other explanations of this large number of female-headed households are the increase in male out-migration and the rising status of women and their occupation of public space activities. With respect to one-person households occupied by a male, it is likely that he has emigrated from a rural area to pursue work in the city. Those one-person households occupied by females, are usually the least privileged socio-economically.

These patterns of family headship and residence are new to the Arab world but they signal new trends in shaping the family in the new millenium. Such changes may also require developing new guidelines in public policies that deal with social security programs, health insurance, and other services.

\subsection{Impact of Migration}

Countries in North Africa have been affected by major social and economic changes that have impacted the family. One of those changes is the increasing 'feminization' of the family as a result of male migration to urban areas within countries, migration to oil-rich countries in the Gulf or migration to European countries in search of better work opportunities. Usually this male exodus leaving women and children behind puts greater pressure on the women to take over responsibilities previously handled by men. As a consequence, women begin to develop competence, and independence. Some studies have shown that when men returned back and tried to exercise their traditional role as patriarchs, they were met with resentment by their wives and children (Hopkins and Ibrahim, 1997 and Mc Murray, 1993).

Among Egyptians, movement that entailed change of residence was traditionally unwelcome and undesirable. However, by the mid 1960s, the changing political, economic and social conditions pushed some of the higher socio-economic classes to emigrate mainly to North America with the intention of staying there. By the mid-1970s, emigration of Egyptians took a different shape with respect to the type of people 
moving, their destination and length of absence. The large majority of emigrants were unskilled or semi-skilled laborers, many of whom came from rural areas. Their destinations were basically the oil-rich countries in the Gulf or Libya. Presumably most of them left alone, leaving their families behind as they did not intend to stay long -just a few years to accumulate some savings to allow them to build or buy a house, or acquire agricultural land or start some business (Amin, 2000).

Though documenting migration levels and trends remains a major challenge to governments, the data presented in Table 8 for all countries in North Africa shows that each country has experienced negative net migration during the last decade of the 20th century. According to the data, the number of migrants including refugees was highest in Sudan and Libyan Arab Jamahirya and lowest in Morocco and Tunisia. Proportionately, the foreign born residents (migrants) in Lybian Arab Jamahiriya were one for every ten of the nationals. Libyan Arab Jamahiriya has been open for foreign labor for a long time, and yet it netted a negative rate of migration.

Table 8: Migration Stock and Net Migration Rates in North Africa Region

\begin{tabular}{|c|c|c|c|c|c|c|c|c|c|c|c|c|}
\hline \multirow[b]{2}{*}{ COUNTRY INDICATOR } & \multicolumn{2}{|c|}{ ALGERIA } & \multicolumn{2}{|c|}{ EGYPT } & \multicolumn{2}{|c|}{$\begin{array}{l}\text { LIBYAN ARAB } \\
\text { JAMAHIRIYA }\end{array}$} & \multicolumn{2}{|c|}{ MOROCCO } & \multicolumn{2}{|c|}{ SUDAN } & \multicolumn{2}{|c|}{ TUNISIA } \\
\hline & 1990 & 2000 & 1990 & 2000 & 1990 & 2000 & 1990 & 2000 & 1990 & 2000 & 1990 & 2000 \\
\hline $\mathrm{CK}^{1}$ & $\begin{array}{c}274 \\
1.1\end{array}$ & $\begin{array}{c}250 \\
0.8\end{array}$ & & & & & & & & & & $\begin{array}{l}38 \\
0.4\end{array}$ \\
\hline & $\begin{array}{l}-30 \\
-1.1 \\
\end{array}$ & $\begin{array}{l}-52 \\
-1.8\end{array}$ & $\begin{array}{l}-90 \\
-1.5\end{array}$ & $\begin{array}{l}-80 \\
-1.2 \\
\end{array}$ & $\begin{array}{l}-3 \\
-0.6\end{array}$ & $\begin{array}{c}-2 \\
-0.4\end{array}$ & $\begin{array}{l}-41 \\
-1.6\end{array}$ & $\begin{array}{l}-44 \\
-1.5\end{array}$ & $\begin{array}{l}-22 \\
-0.8\end{array}$ & $\begin{array}{l}-77 \\
-2.6\end{array}$ & $\begin{array}{c}-9 \\
-1.0\end{array}$ & \begin{tabular}{|l}
-8 \\
-0.8
\end{tabular} \\
\hline
\end{tabular}

1 Estimated mid-year number of non-citizens of the country with the addition of refugees.

2 Estimates represent annual averages for 1990-1995 and 1995-2000. Source: www.un.org/esa/population/publications/ittmig2002/locations/

Over the decade the proportional negative rate of migration has increased in Algeria and Sudan, and decreased slightly in the other countries.

Studies of the impact of the migration of heads of households on families left behind show that such moves are taken in order to generate more income to improve the overall standard of living of family members. On the other hand, these moves entail a measure of sacrifice: on the wives who have to take over the responsibility of running the day-to-day affairs of the household - a task usually carried out by the males; and on the husbands who soon realize that as expatriates in the countries of destination, they have to endure loneliness and hard work as well as living a meager life to have enough savings to send to their families. Studies also show that when these arrangements are prolonged 
over long periods of time, the new arrangements and division of labor among family members left behind start to solidify and become resistant to change, should the husband/father come back (Stack, 2001).

In a comparative study of the impact of migration on the demographic behavior of the populations in Egypt and Morocco, Courbage (1994) asserts that the emigrant is an influential agent of social as well as familial change. The emigrant, who is usually the male head of the household has a major effect on the consumption patterns of members of his household by what he sends or brings with him when he comes for visits. Directly or indirectly, he inspires aspirations towards upward mobility. Often this involves a reevaluation of the costs/benefits of an additional child.

In this context, it is worth mentioning that the destination of migrants plays an important role in shaping the values they acquire along with the material goods. Most Egyptians migrate to oil-rich countries in the Gulf, where pro-natalist values predominate, as these countries have vast resources and relatively small populations. On the other hand, Moroccan migrants as well as Tunisians usually seek work opportunities in Europe, where small families have become the norm. Consequently, the decline in Moroccan fertility was larger than that of Egyptian fertility. Furthermore in Morocco, quite often the emigrant's family leaves the village and moves to the city so as to make better use of the money sent from abroad. In this move, they adopt urban reproductive norms. Also compulsory education is more readily observed in the cities. With increasing educational attainment for girls, continued reduction in fertility behavior is expected.

Some research findings show that absence of the father seems to have an impact on the social, psychological, moral and cognitive development of his children. In the typical patriarchal families, children develop a certain concept of the father as someone who exercises

Table 9: Percentage of Aged Population and Life Expectancy at Birth In North Africa Region

\begin{tabular}{l|c|c|c|c} 
COUNTRY & $\begin{array}{c}\text { Percent 60 yrs and } \\
\text { older (2000) }\end{array}$ & $\begin{array}{c}\text { Percent 60 yrs and } \\
\text { older (2020) }\end{array}$ & $\begin{array}{c}\text { Life Expectancy } \\
\text { Females (2000/05) }\end{array}$ & $\begin{array}{c}\text { Life Expectancy } \\
\text { Females (2015/20) }\end{array}$ \\
\hline Algeria & 6.0 & 9.0 & 71.3 & 75.2 \\
Egypt & 6.8 & 9.6 & 71.0 & 75.2 \\
Libyan Arab & 5.7 & 9.4 & 75.4 & 78.4 \\
Jamahiriya & 6.5 & 9.8 & 70.5 & 74.7 \\
Morocco & 5.5 & 7.4 & 57.1 & 59.8 \\
Sudan & 8.4 & 12.3 & 74.9 & 78.1 \\
\hline Tunisia &
\end{tabular}

Source: U.N. World Population Prospects: The 2002 Revision Population Database. Online: http://esa.un.org/ unpp 
authority and provides protection and security. In cases of children with absent or separated fathers, studies show that father concept becomes distorted, particularly if this absence/separation occurs when the children are quite young. The early father child relationship has been found to be important for the child's self-esteem and selfconfidence. Paternal deprivation seems to result in the development of certain apprehensions in children, as well as impaired development of successful peer relationships (Abdalla, 2001).

\subsection{Demographic Aging}

Declining fertility and declining mortality which results in increase in life expectancy have a profound effect on the age structure of the population (Table 9). According to UN projections, using the medium variant, it is expected that the percentage increase of people aged 60 years and above over a period of 20 years (2000-2020) will range between 35 to 65 percent in the different countries of North Africa. The largest increase in the percentage of older persons is expected in the Libyan Arab Jamahiriya, while in the Sudan that percentage is expected to increase by only 35 percent over the same period. Also the life expectancy of females at birth (which is invariably higher than that of males), a function of declining mortality, ranges between 70 and 75 years, with the exception of Sudan where it is arrested at 57 years (Table 9). Improvements in life expectancy are anticipated to continue in the coming two decades.

The implication of this statistical scenario is that older persons will become more visible in those populations. Furthermore, the growing numbers of older people in a population has major social and economic impacts on the family and on society at large. Issues such as intergenerational solidarity, housing, proposed changes of social security programs, care giving to the old and increasing health care costs are among others that need to be addressed within the framework of Arab culture.

Fargues (1997) notes that due to declining mortality, successive generations live together much longer than they ever did before. At present, many adults still live with their father, who under traditional patriarchal structures holds family wealth and exercises authority. In many cases, the son surpasses the father in education, thus leading to generational conflict and resistance to parental authority.

It was suggested in some studies that the resulting intergenerational conflict and the absence of economic opportunities is a factor that leads young people to be attracted to fundamentalist movements. 
According to research findings, a large proportion of the aged population continue to live with other family members, resulting in extended family households. There is some indication that although the homes for the old people are increasing in numbers, yet the demand exceeds the present supply. The increasing demand for such facilities has grown because more women - who used to be the primary care takers of the older members in the household - are gainfully employed outside the home.

Very little information exists on the health of the older population in the North Africa region. In a study conducted in Egypt and Tunisia (UNDP, 2002), the findings show a high degree of ill health among the older population. Around onethird of older persons perceive themselves as unhealthy and at least 50 percent are suffering from sight problems and have difficulty in walking. Only a very small proportion of those studied scored favorably on scales of high morale or low depression.

As expected, the majority of older perons are females. At this transitional stage in the populations of North Africa, it is most likely that those women are uneducated and have not been involved in gainful employment. In other words, they are likely to be unrecognized by social security systems existing in those countries. Thus the major burden of taking care of that sector of the population remains with the family.

\subsection{HIV/AIDS Pandemic}

Information about HIV/AIDS in the region is insufficient. In most of the countries, systematic surveillance remains weak. According to UNAIDS and WHO, by December 2001, the number of people living with HIV/AIDS world wide was estimated to be 40 million (UN. UNAIDS, Global Summary). Of those 440,000 adults and children, or a little over 1 percent, were living in the North Africa and Middle East Region (UN.UNAIDS. Regional HIV/AIDS). These constitute 0.2 percent of the adult population of the region (15 to 49 years old using 2001 population estimates). Of those 40 percent were women. This prevalence rate of HIV/AIDS is relatively low in comparison with other global rates. It is second to the East Asia and Pacific region and Australia and New Zealand. The main modes of transmission in those populations are due to heterosexual transmission and transmission through injecting drug use. Despite the late arrival of HIV/AIDS in the region, in the late eighties, there are indications that there is an increase in the HIV infection rates in some countries in the region. What aggravates the situation, and allows for the continued increase in the infection rates is the reluctance of some governments in the region 
to acknowledge its presence, much less to adopt measures to combat it (UN.UNAIDS. Fact Sheet).

According to the Fact Sheet 2002 of UNAIDS, an estimated 83,000 people in the Middle East and North Africa region acquired the virus in 2002 (UN.UNAIDS. Fact Sheet 2002). Most of the countries of the region, particularly those of North Africa lack adequate monitoring systems that would measure accurately the development of the epidemic. It is believed that there may have been significant outbreaks of HIV infections among injecting drug users, particularly in countries in North Africa.

In Morocco, the National AIDS Control Programme has noted the relatively high prevalence of other STD's, which signifies that unsafe sex is more common than might be assumed (UN.UNAIDS: Fact Sheet 2002).

In a survey of family health conducted in Tunisia in 2001, a national sample of about 4000 women who had ever been married (15-49 years old) were interviewed. The interview schedule included questions about knowledge of STD's. The findings show that about 90 percent of the respondents know about HIV/AIDS (Arab Family Health Project, 2002). However, there was major variation between urban and rural residents and their knowledge of the disease ( 95 and 79 percent respectively).

With respect to the source of information, 95 percent of those with knowledge, obtained their information from the TV, while 28 percent know of it from the radio. The survey also asked about knowledge of how the virus is contracted. The findings show that 78 percent of the respondents who know it, said "through sexual relations", while 29 and 23 percent respectively said "through blood transfusion" and "injections". The data show substantial variation in the knowledge of the respondents according to their level of education. Higher percentages of respondents with higher levels of education know of HIV/AIDS than those with lower educational attainment. With respect to preventive measures, the findings of the survey show that about 59 percent of the respondents knowing about HIV/AIDS, said "using the condom", 16 percent said "avoid blood transfusion", and 13 percent said "avoid injections" (Arab Family Health Project, 2002).

Due to the nature of the virus and how it is transmitted, and also the denial of several governments in the region to acknowledge its presence, the World Health Report, 2002 argues that . "most people infected with HIV do not know they are infected, making prevention and control more difficult" (WHO, 2000, p. 62). Therefore, it could be argued that in such situations more children would be orphaned, marriage partners 
widowed, and household economies negatively affected as the infected person -most likely to be the head of the household- withers away and dies. Furthermore, even in case of diagnosis, family members of the infected person would be ashamed to admit it for fear of being ostracized by their communities. This denial of its presence is exemplified in the Egyptian TV, through a particular commercial that shows a young man travelling abroad, and being told that abroad people use condoms to protect themselves from HIV/AIDS, however, "our" men are protected because they do not indulge in such behavior, as it is against religious teachings.

Another observation to be made here is that use of condoms has not been popular, even as a family planning method mainly because of a prevailing belief that protection against unwanted pregnancy is the woman's responsibility. Concomitant with that is the belief that condoms are associated with illicit sex. That exposes females to contacting various types of STD's that their husband may have acquired.

\subsection{Impact of Globalization}

In the absence of an agreed upon definition of the concept of "globalization," one can think of it as a derivative resulting from advancement in science and technology, particularly in information and communication technology (ICT). The speed by which such fields are changing is overwhelming. As a consequence links are being established across the globe resulting in establishment of powerful associations in economic fields, mass media, entertainment and the like. Sometimes such links destroy or wipe away small enterprises. One major issue with these processes is that no one seems to be immune from its impact.

Two measures through which globalization can filter into the lives of people are through education and use of ICT yet these are areas in which countries of the region lag behind. According to data presented in Table 10 , the proportion of adult illiterate females ( 15 years and older) range from one in every three in Libyan Arab Jamahirya to almost two in every three in Morocco. That proportion is substantially lower among males ranging from one in every ten in Libyan Arab Jamahiriya to almost four in every ten in Morocco. With respect to the average number of years that students (both sexes) spend in schools, again the data reflect poor attendance ranging from an average of two years in the Sudan to 5.5 years in Egypt (Table 10). Although these figures reflect an improvement compared to earlier dates, yet more needs to be done in that regard. 
Table 10: Percent of Adult Illiterates (15 years and older) and Mean Years of Schooling

\begin{tabular}{l|c|c|c}
\cline { 2 - 4 } & \multicolumn{2}{|c|}{ ADULT HLITERACY RATE (\%) 1999} & MEAN YEARS OF SCHOOLING 2000 \\
\cline { 2 - 4 } COUNTRY & MALES & FEMALS & 54.3 \\
Algeria & 22.6 & 57.2 & 5.5 \\
Egypt & 33.9 & 33.1 & $3.5(1992)$ \\
Libyan Arab Jamahiriya & 9.8 & 64.9 & $3.0(1992)$ \\
Morocco & 38.9 & 55.1 & 2.1 \\
Sudan & 31.1 & 40.7 & 5.0 \\
Tunisia & 19.6 &
\end{tabular}

Source: UNDP, The Arab Human Development Report 2002, p. 151.

Table 11. Selected Indicators of ICT In North Africa

\begin{tabular}{l|c|c|c}
\hline Country & $\begin{array}{c}\text { Number of PC's } \\
\text { (per 1,000 people) } 1999\end{array}$ & $\begin{array}{c}\text { Number of Web Sites } \\
\text { (per 10,000 people) 2000 }\end{array}$ & $\begin{array}{c}\text { Total number of Internet } \\
\text { Users (in thousands) }\end{array}$ \\
\hline Algeria & 6 & 0 & 0 \\
Egypt & 12 & 1 & 7 \\
Libyan Arab Jamahiriya & 0 & 0 & 1 \\
Morocco & 11 & 0 & 2 \\
Sudan & 3 & 0 & 0 \\
Tunisia & 15 & 0 & 12 \\
\hline
\end{tabular}

Source: UNDP, The Arab Human Development Report 2002, p. 156.

As to ICT, Table 11, shows some selected indicators such as availability of PC's in population and number of internet users. Once more the data shows the dearth of availability and use of such technology. Nonetheless, the impact of globalization is seeping into the culture and impacting the social system.

Some scholars explain the re-emergence and increasing use of the 'hijab' in Arab societies as a response to pressures of Westernization sweeping over the region.Amin (2000) argues that wearing the hijab (veil) should not be considered as a sign of narrow-midedness or fanaticism, as many may think, but rather it represents a desire on the part of women towards greater movement into the outside world. It gives their guardians -father, brother or husband-some assurance that these women are protected from harassment.

In urban Muslim societies, the veil represents physical and emotional security. It allows its users more freedom of movement in public space. This view is completely the opposite of the Western view of the veil - being a tool for confinement and restricting women's freedom.

Hessini's study of Moroccan women (1994) asserts that women wear the veil to project their Muslim identities. Such women are often outspoken and articulate rather than being suppressed and subdued. The 
subjects in Hessini's study are educated, urban women who deliberately chose to wear the veil out of conviction and desire to express outwardly their Muslim faith. The study shows that the notion of gender equality that leads to competition among men and women is not there. On the other hand, within the family and in society at large there is complementarity of roles assigned to men and women. Usually the father is assigned the leadership role, he works outside the home to support his family, while the mother is assigned the role of the educator of her children, training them in religious and cultural traditions, while maintaining the household. This complementarity of roles upholds societal cohesion. The division of roles is spelled out in the Personal Status Code of the Government of Morocco. However in reality, in Morocco, as well as in other countries in North Africa women may choose to work, even if they do not need that financially, or may have to work to support or supplement the family income.

According to some scholars, globalization seems like a doubleedged sword, having both positive and negative impacts on the lives of ordinary citizens, particularly females (Doumato and Posusney, 2003). Most of the economies of the countries in the region were controlled by the state for the large part of the second half of the 20th century, and the state encouraged women to participate in the labor force by joining the public sector. They did that by offering them job security, as well as many other privileges such as a various types of leaves of absence, some of which were paid, to take care of another family member. Clearly under structural adjustment programs and the move towards privatization, such privileges will not be tolerated. That raises the question "Will the woman go back to the home or will she succumb to the changing work conditions? Should she choose the former that may have an influence on fertility rates, perhaps reversing the decline.

Nassar (2003) and Assaad (2003) clearly note that globalization tends to reduce work opportunities for females in the formal sector, therefore affecting the micro-level economy of the household income.

\section{NEW CHALLENGES}

Entering a new millenium, there are numerous challenges that face humanity in general and individual lives in particular. At the micro level in the North African region, the family remains a basic institution, although its structure has changed. Women are getting married at an older age, which in turn affects their fertility level, so they are producing fewer children. Part of the reason for delayed marriages is that they 
spend more years in schools. This also has led to an increase in the numbers who are joining the labor force. Governments are encouraging females to participate in the labor force by offering them special privileges. Women's participation in the labor force has had some consequences affecting domestic relations among family members, such as distribution of labor within the household, and decision making processes. Husbands of working women participate in some household responsibilities in return for the wife's sharing in expenses. Also, working women are consulted in major decisions affecting family life. Generally speaking, the employment of women contributes to higher standards of living of their families.

Globalization and new technologies have ushered in remarkable opportunities. In the meantime they also signaled new threats. Fargues (1997) argues that as a result of the spread of technical knowledge and its acquisition through mass education, the hierarchial structure of the traditional family pattern is challenged. The young people now are more educated than their elders, thus questioning their authority. He also argues that women are on the way of overtaking men. According to Fargues, these changes are likely to cause social rupture in the Maghreb (North Africa region).

As a reaction to the influence of Western culture which has become accessible through the spread of globalization, religious fundamentalism is gathering momentum and looking for opportunities to emerge and take over. Though its ultimate objective is political dominance, yet it tries to manifest itself in various spheres of the social structure. In gaining legitimacy and acceptance, it advocates imposition of Islamic law. One of the easiest manifestations of this exercise is to deprive women of those few rights they struggled to earn. The arena where this exercise begins would be the family which is still managed by patriarchal relations. Supported by other structures in society, coercion rather than persuasion would be exercised particularly in social areas such as women's rights. Barakat (1993) quotes an interview on Algerian television in which Abbassi Madani, who is considered a moderate leader of the Islamic Salvation Front, showed some flexibility and tolerance when responding to some controversial political questions. However, that flexibility and tolerance disappeared completely when the questions addressed social issues and women's rights. "Serious questions were met with accusations, threats, and evasive generalities. He called Algerian women activists, including two of his interviewees, 'eagles of neocolonialism' and 'the daughters of Jeanne d'Arc,' and warned one of them quite explicitly, saying, 'If your demands [such as the right of women to seek divorce] conflict with the requirements of 
the Shari'a, then I do not believe that a Muslim woman could say there is no God but God and Muhammad is the messenger of God and still reject the application of the Islamic Shari'a." (p. 281)

The forces of social change taking place in many parts of the world are also sweeping over countries in the North Africa region. Those changes are affecting all existing social institutions, be it political, economic, social or religious. Clearly the family institution is also challenged by these changes. The centrality of the family as a basic socioeconomic unit is challenged foremost by the state. The state is controlling the educational institution and is getting to be the biggest employer. Many young men and women are pursuing education and employment away from their parents in urban areas within and outside their countries. These expanding economic opportunities, industrialization and urbanization have led to the appearance of bourgeois classes and cultures. However, despite these structural changes which have started to weaken traditional relations, roles and statuses, as well as value orientations within the family, Barakat (1993) contends that "Young men and women show less alienation from the family than from any other social institutions, be it religious, political or social" (p. 100).

\section{POLICY IMPLICATIONS}

Given the pervasive social changes overcoming all social systems in society including the family, what is the role of public policies in building capabilities and putting them to effective use? First and foremost, public policy should address and promote human development. In North Africa like the rest of the globe, women constitute half the population. Therefore public policy should encourage and implement egalitarianism at all levels within society and that would infiltrate among family members as well (Barakat, 1993). Female education as expressed in literacy rates and school enrolment has increased proportionately in the past few decades. However, illiteracy is still rampant among women.

El-Mikawy (1999) in her case study of Egypt argues that globalization may have contributed to improvements in living conditions of some members of the society in different countries in the region. However, women may have suffered more negative consequences as a result of various policies aimed at implementing structural adjustments as well as other economic policies in favor of globalization. More working women were pushed into the informal sector, where they would not be covered by social security programmes, nor health insurance and other fringe benefits. As a matter of fact, joining the informal sector signals a return to the role of the family as a production unit. In that case, women are expected to shoulder larger family responsibilities. Under these conditions, conservative discources grow louder discouraging 
women from contributing to the civil society and pushing forward their domestic role.

Murphy (2003) presents a similar picture of Tunisian women despite major efforts undertaken by the government since Bourguiba became the country's first president in 1957. The study highlights a number of laws and reforms promulgated to support women. Yet the author attests to the negative consequences that some of the economic liberalization programmes have had on women in pushing them out of the mainstream public life.

In Sudan a similar picture is presented by Hale (2003) in her study. However in the case of Sudanese women, some of them took up servicing the "militias" in an effort to help the Islamic nation.

Women also suffer from unequal citizenship and legal entitlement, particularly in handling affairs of her children when they are in her custody.

Public policy needs to redress inequality of opportunity offered to women, which is reflected in employment status, wages, and occupational discrimination. In Algeria, for example, the Family code, passed in 1984, legalized inequality between women and men in marriage, divorce, child custody and inheritance. It states that women's work is conditioned by her husband's approval. Women are treated as second class citizens who enjoy artificial rights. Furthermore, men are allowed to vote for their wives.

In other countries, women continue to be marginalized and discriminated against in both law and custom. Public policy should address empowerment of women in all spheres. Adoption of the Convention on the Elimination of All Forms of Discrimination against Women (CEDAW) would constitute a primary step in that direction.

Public policy addressing health issues are paramount. Infection with HIV/AIDS virus is accelerating world wide. No region is immune. Acknowledging its existence, educating people about it and implementing preventive measures to fight it is the responsibility of the state.

Education is a basic human right. It is the means for improved productivity and general well-being. Nonetheless, education is also an end in itself. Quantitatively there has been an increase in school enrollment, however the quality of the educational input requires more attention. 
Public policy needs to support other values that are instrumental for human development such as tolerance of minority groups, rights of children, adolescents as well as the aged.

Addressing these issues in a creative and comprehensive manner would allow the family to maintain its pivotal position in society.

\section{BIBLIOGRAPHY}

ABDALLA, J.G. "The Absent Father" in Nicholas S. Hopkins (ed.) The New Arab Family. Cairo Papers in Social Science. Vol. 24, No. 1/2, Spring/Summer 2001, pp. 214-246.

AMIN, G. Whatever Happened to the Egyptians?: Changes in Egyptian Society from 1950 to the Present. Cairo: The American University in Cairo Press, 2000.

ASSAAD, R. "Gender and Employment: Egypt in Comparative Perspective" in E.A. Doumato, and M.P. Posusney (eds) Women and Globalization in the Arab Middle East: Gender, Economy, and Society. Boulder: Lynne Rienner Publishers, 2003, pp. 119-141.

Arab Family Health Project, Tunisian Family Health Survey: Principal Report. Tunisian Republic: Ministry of Public Health 2002. (in Arabic)

BARAKAT, H. The Arab World: Society, Culture, and State. Berkeley: University of California Press, 1993.

COURBAGE, Y. "Demographic Change in the Arab World: The Impact of Migration, Education and Taxes in Egypt and Morocco." Middle East Report, 190. Vol. 24, No. 5, Sept-Oct, 1994, pp. 19-22.

DOUMATO, E.A. and POSUSNEY, M.P. (eds.) Women and Globalization in the Arab Middle East: Gender, Economy, and Society. Boulder: Lynne Rienner Publishers, 2003.

EL-MIKAWY, N. "The Informal Sector and the Conservative Consensus: A Case of Fragmentation in Egypt". In Haleh Afshar and Stephanie Barrientos (eds.) Women, Globalization and Fragmentation in the Developing World. London: Macmillian Press Ltd., 1999, pp. 77-90.

FARGUES, P. "From Demographic Explosion to Social Rupture". In Nicholas Hopkins and Saad Eddin Ibrahim (eds.) Arab Society, Class, Gender, Power, and Development. Cairo: The American University in Cairo Press. 1997, pp. 75-83.

FARGUES, P. "Terminating Marriage". In Nicholas S. Hopkins (ed.) The New Arab Family. Cairo Papers in Social Science. Vol. 24, No. 1/2, Spring/Summer 2001, pp. 247-273.

FERNEA, E.W. (ed). Women and Family in the Middle East: New Voices of Change. Austin: Univ. of Texas Press, 1985.

GOCEK, F.M. and BALAGHI, S. (eds.) Reconstructing Gender in the Middle East: Tradition, Identity and Power. New York: Columbia University Press, 1994.

HALE, S. "Sudanese Women in National Service, Militias, and the Home". In E.A. Doumato and M.P. Posusney (eds.) Women and Globalization in the Arab Middle East: Gender, Economy, and Society. Boulder: Lynne Rienner Publishers, 2003, pp. 195-213.

HESSINI, L. "Wearing the Hijab in Contemporary Morocco: Choice and Identity". In Fatma Muge Gocek and Shiva Balaghi (eds.) Reconstructing Gender in The Middle East: Traditions, Identity and Power. New York: Columbia University Press, 1994, pp. 40-56.

HOODFAR, H. Between Marriage and the Market. Cairo: The American University in Cairo Press, 1999.

HOPKINS, N.S. (ed.) "The New Arab Family". Cairo Papers in Social Science. Vol. 24, No. 1/2, Spring/Summer 2001. 
HOPKINS, N.S. and IBRAHIM, S.E. (eds.) Arab Society: Class, Gender, Power, and Development. Cairo: The American University in Cairo Press, 1997. 